\title{
STRATEGI KOMUNIKASI PEMASARAN PT. OJEK SYAR'I
}

\author{
Firly Aviliani
}

\author{
Universitas Islam Negeri Sunan Ampel Surabaya \\ aviliani@gmail.com
}

Article Info

\section{Article history:}

Received 16 August 2018

Accepted 15 September 2018

Published 10 Oktober 2018

\section{Keyword:}

Strategis komunikasi pemasaran, ojek online dan syar'i

\section{Abstract}

Artikel ini membahas tentanng bagaimana strategi komunikasi pemasaran PT. Ojek Syari. Tujuannya adalah untuk mengungkap fakta dan data mengenai strategi komunikasi pemasaran PT. Ojek Syari. Metode yang digunakan adalah penelitian kualitatif yang dengan pendekatan deskriptifkualitatif.

Hasil penelitian ini adalah Pertama, strategi segmentasi, langkah awal PT. Ojek Syar'i dalam penentuan segmentasi mengambil sasaran wanita dan anak-anak yang dibungkus dengan basis syar'i. Kedua strategi komunikasi pemasaran PT. Ojek Syari adalah melalui media sosial marketing yaitu melalui media $T V$, radio, cetak, media instagram, youtube, facebook kontenisi dari sosial media ini berdasarkan syari'i yaitu lebih mengutamakan aspek Islami sistem syar'i.

Ketiga dalam PT. Ojek Syari diterapkan sistem syar'i pada pembagian hasil, proses perekrutan, proses promosi, konten sosial media, sampai tata cara berkendara yang syar'i, dan cara berpakaian

\section{Editorial Office:}

Program Studi Ilmu Komunikasi, Fakultas Dakwah dan Komunikasi, UIN Sunan Ampel Surabaya. Jl. Ahmad Yani 117 Surabaya, Jawa Timur, Indonesia.

Email: jurnalilkom@uinsby.ac.id 


\section{Pendahuluan}

Teknologi merupakan aplikasi ilmu dan engineering untuk mengembangkan mesin dan prosedur agar memperluas dan memperbaiki kondisi manusia atau paling tidak memperbaiki efisiensi manusia pada beberapa aspek. Manusia menciptakan teknologi dengan tujuan agar apa yang dikerjakan dengan bantuan teknologi menjadi lebih mudah dan lebih efisien dalam penggunaannya. Teknologi informasi dan komunikasi adalah salah satu yang memiliki tingkat perkembangan yang cukup pesat dan saat ini dunia berada pada era informasi dimana informasi memegang peranan penting dalam aspek kehidupan, siapa yang menguasai informasi maka ia memiliki peluang lebih dibandingkan yang tidak memiliki.

Internet sudah sangat mempengaruhi sendi-sendi kehidupan interaksi masyarakat dunia pada umumnya dan masyarakat Indonesia khususnya, tidak hanya seputar industri media massa konvensional yang beralih menjadi industri media online atau industri di bidang perdagangan yang beralih menjadi industri belanja online, pembanyaran tagihan pun seperti listrik, air, cicilan rumah, pembelian tiket bisa melalui online, namun kini setiap kebutuhan yang diperlukan di setiap sendi masyarakat berupa layanan aplikasi digital online. Berbagai macam aplikasi tersebut tersaji dalam handphone berbasis android ataupun IOS yang merangkum banyak kemudahan bagi individu-individu dalam menjalankan rutinitas kesehariannya termasuk industri transportasi berbasis online. Berdasarkan hasil survei dari Asosiasi Penyedia Jasa Internet Indonesia (APJII) serta We Are Social menyebutkan bahwa pengguna internet Indonesia berada di kisaran 54,68\%. ${ }^{1}$

Fenomena perkembangan teknologi saat ini yang paling ramai dibicarakan dan menjadi bahan diskusi banyak kalangan adalah mengembangkan teknologi ke arah bisnis transportasi yang modern dengan menggunakan kecanggihan aplikasi di dunia virtual. Masyarakat saat ini sangat dimudahkan dengan adanya sarana transportasi ini terutama untuk pemesanannya. Dimanapun dan kapanpun juga secara cepat dan real time, masyarakat mudah melakukan mobilisasi kemana saja dengan memiliki aplikasi ini.

Dalam dua atau tiga tahun belakangan, pertumbuhan penggunaan transportasi online meningkat sangat tajam, baik dilihat dari jumlah pengemudi atau armada ataupun penumpang, yang meliputi roda dua dan roda empat. Alasan praktis dan tarif relatif murah menjadi latar belakang booming-nya layanan transportasi berbasis daring ini. Hal ini dibuktikan dari survei yang dilakukan Yayasan Lembaga Konsumen Indonesia, survei yang dilakukan pada 5-16 April 2017, melibatkan 4.668 (empat ribu enam ratus enam puluh delapan) responden. sebanyak 55 persen merupakan konsumen laki-laki, dan 45 persen adalah konsumen perempuan, dari 4.668 responden konsumen, sebanyak 55 persen

\footnotetext{
${ }^{1}$ Hasil Survei Penetrasi dan Perilaku Pengguna Internet Indonesia 2017, https://apjii.or.id, diakses pada 27 Januari 2018.
} 
menggunakan transportasi online jenis mobil dan motor; sedangkan yang hanya menggunakan jasa motor sebanyak 21 persen dan menggunakan mobil saja sebanyak 24 persen. Responden survei didominasi oleh usia kerja atau dengan kata lain bahwa kehadiran transportasi online banyak dimanfaatkan oleh mereka yang berusia produktif yaitu usia 15-64 tahun. ${ }^{2}$

Ketua Yayasan Lembaga Konsumen Indonesia Tulus Abadi mengatakan 72,6 persen dari 4.668 responden pengguna jasa transportasi online memilih Go-Jek. "GoJek menduduki rating tertinggi dipilih konsumen,"Menurut Tulus, di bawah GoJek, Grab dipilih 66,9 persen responden. Sedangkan Uber digunakan 51 persen dan My Bluebird 4,4 persen. Dari frekuensi penggunaannya, 31,6 persen pengguna paling banyak menggunakan Ojek online 2-3 kali dalam seminggu.

Sebagian besar target segmentasi pengendara dari transportasi online adalah pria atau wanita umur 21 tahun sampai 55 tahun, sedangkan pelanggan yaitu pria atau wanita dengan usia produktif mulai dari pelaku bisnis, pelajar, pegawai dan lainlain. Dengan langsung menggunakan aplikasi login atau registrasi terlebih dahulu berupa informasi pribadi, seperti nama, alamat email, dan nomer telepon seluler setelah itu aplikasi sudah siap digunakan dengan menentukan lokasi penjemputan dan lokasi tujuan.

2 Tim Peneliti YLKI, Warta Konsumen Transportasi Online Kawan atau Lawan, http://ylki.or.id, diakses pada tanggal 28 Januari 2018.

3 Umaimah Wahid dan Anggun Eka Puspita, "Upaya Peningkatkan Brand Awareness PT. GoJek Indonesia Melalui Aktivitas Marketing Public
Dengan persaingan yang sangat ketat setiap perusahaan dituntut harus mampu mempertahankan perusahaan mereka yaitu, dengan komunikasi pemasaran yang baik dalam mempromosikan produk atau jasa yang ditawarkan dari perusahaan tersebut, agar produk dari perusahaan dapat dikenal dimasyarakat luas. ${ }^{3}$

Berdasarkan penelitian Marsela Citra A, strategi pemasaran yang dilakukan PT. Go-Jek meliputi melakukan kegiatankegiatan yang mendukung pembentukan bahkan penguatan image perusahan secara terencana dan terus-menerus sehingga diharapkan dapat memenangkan hati masyarakat. komunikasi pemasaran melalui internet Go-jek Indonesia memanfaatkan media youtube sebagai tempat untuk mengunggah berbagai video yang mengkomunikasikan tentang bisnis Go-jek, selain itu dengan tambahan jasa lain yang ditawarkan oleh Go-jek (Go-big, Go-mart, Gofood, dan Go-tix), event yang diselenggarakan oleh Go-jek Indonesia. ${ }^{4}$

Berbeda dengan PT. Uber Indonesia Technology, komunikasi pemasarannya mencakup bauran pemasaran (marketing communication mix) yaitu, advertising, sales promotion, event and experience, public relation and publicity, direct marketing, interactive marketing, word of mouth marketing, dan personal selling.dengan menggunakan delapan bauran komunikasi pemasaran ini, PT uber

Relation” . Jurnal Komunikasi Vol. 9, No. 1, Juli 2017, hlm $31-43$.

4 Marsela Citra A, "Manajemen Komunikasi Pemasaran di Media Online (Studi Kasus terhadap Manajemen Komunikasi Pemasaran yang Dilakukan oleh GO-JEK di Media Online)'”. Skripsi (Yogyakarta: Universitas Gadjah Mada,2017) hlm. $2-3$ 
Indonesia Technology dapat meningkatkan minat konsumen untuk menggunakan aplikasi transportasi besbasis online Uber di Indonesia. ${ }^{5}$

Di tengah pesatnya transportasi berbasis aplikasi online seperti Go- Jek, Grab Bike, Uber umumnya pengendaranya adalah laki-laki dan penumpangnya secara acak, membuat penumpang kurang nyaman utamanya untuk perempuan namun, beberapa aplikasi seperti PT. Ojek Syari , Lady Jek, Ojesa (Ojek Salimah), dan Ojek Amanah segmentasinya adalah pengemudi dan penumpang khusus perempuan.

Berawal dari ide founder yaitu kesulitan menggunakan ojek online karena rata-rata pengendara ojek online adalah laki-laki jadi para perempuan sedikit khawatir dari segi kenyaman dari situ tahun 2015 terbentuklah PT. Ojek Syari sebagai aplikasi mobile untuk mempermudah tranportasi perempuan dan dari situ juga peluang besar PT. Ojek Syari masuk dalam dunia transportasi online dilihat cukup tingginya kaum perempuan menggunakan jasa transportasi online. Dari sejak awal berdiri hingga sekarang PT. Ojek Syari mengalami peningkatan mulai dari driver, pelanggannya, pelayanan, fasilitas.

PT. Ojek Syari hadir di latar belakangi banyaknya pelecehan seksual yang terjadi di transportasi umum terhadap perempuan namun berdasarkan survei Kompas.com dan Inside.id tahun 2015, $70 \%$ penumpang transportasi umum adalah wanita, namun pada realitasnya ada

5 Muhammad Dipo Trinanda Talaohu, "Komunikasi Pemasaran Transportasi Berbasis Online”. Skripsi (Bandung: Universitas Islam Bandung) hlm. 165 masalah keamanan yang dihadapi wanita dimana berdasarkan data Komisi Nasional HAM wanita sejak tahun 1998-2011 terjadi 22.284 kasus pelecehan seksual di ruang publik dan transportasi umum di Indonesia, atau dengan kata lain setiap harinya terdapat empat (4) wanita yang menjadi korban pelecehan seksual di transportasi umum dan ruang publik. Dan berdasarkan survei yang dilakukan oleh Thompson Reuters dan YouGov di enam belas (16) negara dengan 6.550 responden $70 \%$ wanita pengguna transportasi umum akan merasa lebih aman jika transportasi tidak bercampur dengan pria atau khusus wanita. Dan hingga saat ini, transportasi khusus wanita hanya ada KRL khusus Wanita.

Dalam laman berita online Sindonews.com seorang driver ojek online diduga telah melakukan pelecehan seksual terhadap salah seorang penumpangnya siswi SMA yang berada di wilayah Pasar Minggu, Jakarta Selatan. Kejadian ini mulai beredar di media sosial (medsos), terutama Kaskus pada Sabtu 13 Februari 2016. ${ }^{8}$ Selain kasus tersebut beberapa bulan lalu terdapat kasus pelecehan seksual dari laman berita Tribun News pada Maret 2018 yang diduga dilakukan oleh pengemudi ojek online kepada penumpangnya seorang perempuan namun kekesaran seksual melalui media elektronik pesan. ${ }^{6}$

\section{Kajian Pustaka}

\section{Komunikasi Pemasaran}

Pemasaran merupakan kegiatan penting dalam sebuah perusahaan,

${ }^{6}$ http://www.tribunnews.com/2018/03/28/harussemakin-waspada-wanita-ini-dapatkan-driver-ojekonline-terang-terangan-mengajaknya-check-in diakses pada tanggal 27 Juli 2018. 
pemasaran bukanlah semata-mata kegiatan seperti menjual dan mempromosikan sesuatu, melainkan sebuah konsep yang menyangkut suatu sikap mental, cara berfikir yang membimbing untuk melakukan suatu kegiatan, kegiatan itu tidak selalu berupa menjual suatu benda, tetapi juga menjual gagasan-gagasan, karier, tempat (tempat wisata, rumah, lokasi industri), undang-undang (misalnya UU lalu lintas), jasa (transportasi, kesehatan, perdagangan, jasa potong rambut), hiburan (pertunjukan, pertandingan) dan kegiatan-kegiatan nirlaba seperti yayasan-yayasan sosial dan keagamaan. $^{7}$

Menurut Rheland Kasali yang mengutip dari American Marketing Associations mendefinisikan pemasaran sebagai: Suatu proses perencanaan dan eksekusi, mulai dari tahap konsepsi, penetapan harga, promosi, hingga distribusi barang-barang, ide-ide, dan jasajasa, untuk melakukan pertukaran yang memuaskan individu dan organisasi. ${ }^{8}$

Pada dasarnya komunikasi pemasaran terdiri dua bidang keilmuan komunikasi dan pemasaran penggabungan dari dua kajian tersebut menghasilkan kajian baru. Pemasaran dan komunikasi sangatlah berhubungan erat. Komunikasi merupakan proses pengoperan lambanglambang yang diartikan sama anatar individu dengan individu, individu dengan kelompok, kelompok dengan kelompok,

\footnotetext{
7 Rhenald Kasali, Segmentasi, Targeting, dan Positioning, (Jakarta: PT. Gramedia Pustaka Utama, 2007) hlm 52.

${ }^{8}$ Rhenald Kasali, Segmentasi, Targeting, hlm. 53.

9 Soemanegara, Strategic Marketing Communication, (Bandung: Alfabeta, 2006) hlm. 3
}

kelompok dengan massa. Komunikasi dalam pemasaran bersifat kompleks, artinya bentuk komunikasinya lebih rumit mendorong penyampaian pesan oleh komunikator kepada komunikan dilakukan melalui sejumlah strategi komunikasi yang canggih, setelah melewati proses perencanaan yang matang. ${ }^{9}$

Komunikasi pemasaran dapat juga disebut sebagai kegiatan komunikasi yang ditujukan kepada pelanggan dengan menggunakan berbagai media ini dapat dipergunakan dengan harapan dapat memunculkan tiga tahap perubahan, yaitu perubahan pengetahuan, perubahan sikap dan perubahan tindakan yang dikehendaki. Beberapa media yang dapat digunakan, misalnya poster, banner, pamflet, televisi, radio, majalah dan surat $\operatorname{kabar}^{10}$.

Menurut Lenny Meyrin Evelyn Lengkey yang mengutip dari Djasmin Saladin Komunikasi pemasaran adalah aktivitas yang berusaha menyebarkan informasi, mempengaruhi dan membujuk atau meningkatkan pesan sasaran atas perusahaan dan produknya agar bersedia menerima, membeli loyal pada produk yang ditawarkan perusahaan yang bersangkutan. ${ }^{11}$

Komunikasi pemasaran adalah aplikasi komunikasi yang ditujukan untuk membantu kegiatan pemasaran sebuah perusahaan. Aplikasi tersebut sangatlah dipengaruhi oleh berbagai bentuk media yang digunakan, daya tarik pesan dan

\footnotetext{
${ }^{10}$ Soemanegara, Strategic Marketing, hlm 4.

11 Lenny Meyrin Evelyn Lengkey Debby Kawengian Eva Marentek, “Peranan Komunikasi Pemasaran dalam Meningkatkan Minat pengguna Iklan di Harian Komentar Manado ”, Journal "Acta Diurna”, Volume III. No.3. Tahun 2014, hlm. 4
} 
frekuensi penyajian data. Penerapan komunikasi bisnis sangatlah penting, khususnya dalam penyampaian pesanpesan komunikasi komunikasi yang dihadapkan pada berbagai persoalan, seperti: perbedaan persepsi, perbedaan budaya, dan keterbatasa media yang digunakan.

\section{Metode Penelitian}

Penelitian yang peneliti gunakan adalah jenis penelitian kualitatif. Jenis penelitian menggunakan penelitian kualitatif, peneliti mendeskripsikan wawancara mendalam terhadap subyek penelitian. Hasil wawancara berupa katakata tertulis maupun lisan dari subyek penelitian, selanjutnya peneliti memberi makna secara kritis pada realitas yang dikontruksi subyek penelitian.

Pendekatan ini menggunakan pendekatan manajemen pemasaran, sedangkan spesifikasi penelitian yang digunakan adalah kualitatif deskriptif yang bertujuan mengumpulkan informasi ataupun data untuk disusun, dijelaskan dan dianalisis.

Dalam penelitian ini, alasan peneliti mengambil penelitian kualitatif deskriptif adalah untuk menjelaskan subjek penelitian secara rinci. Sehingga penelitian ini dapat memperoleh hasil yang lebih mendalam terkait pelaku perusahaan dalam melaksanakan aktivitas merencanakan komunikasi pemasaran berdasarkan konsep bauran pemasaran (marketing mix), untuk dapat menjelaskan penerapan strategi komuniksi pemasaran PT. Ojek
Syari . Dan kemudian hasil penelitian ini dapat dideskripsikan dalam bentuk katakata dan bahasa.

\section{Strategi Komunikasi Pemasaran}

Secara etimologi adalah turunan dari kata dalam bahasa Yunani, strategos. Adapun strategos dapat diterjemahkan sebagai "komandan militer" pada zaman demokrasi Athena. Awalnya istilah strategi dipergunakan dalam dunia militer yang dimaksudkan sebagai cara penggunaan seluruh kekuatan militer untuk memenangkan suatu peperangan. ${ }^{12}$

Menurut Onong Uchjana Effendy mengutip dari David Hunger dan Thomas L. Wheelen, strategi adalah serangkaian keputusan dan tindakan manajerial yang menentukan kinerja perusahaan dalam jangka panjang. Manajemen strategi meliputi pengamatan lingkungan, perumusan strategi (perencanaan strategis atau perencanaan jangka panjang), implementasi strategi dan evaluasi, serta pengendalian.

Dari definisi diatas dapat disimpulkan bahwa strategi merupakan gabungan dari kegiatan perencanaan jangka panjang, pengambilan posisi atau penyesuaian diri serta evaluasi sebuah perusahaan dalam lingkungannya. Strategi pemasaran menurut Nugroho J. Setiadi merupakan sebuah rencana yang didesain untuk mempengaruhi pertukaran dalam mencapai tujuan organisasi ataupun perusahaan, biasanya strategi pemasaran diarahkan untuk meningkatkan kemungkinan atau frekuensi perilaku 
konsumen, seperti peningkatan pembelian produk pada perusahaan tertentu atau kunjungan pada toko tertentu. ${ }^{13}$

\section{Pemasaran Basis Syar'i}

Menurut Bukhari Alma dan Donni Juni Priansa, pemasaran Islami adalah sebuah dasar bisnis strategis yang mengarahkan pada, penawaran, dan perubahan values dari satu inisiator kepada stakeholders-nya, yang di dalam seluruh prosesnya sesuai dengan akad serta prinsip-prinsip al- Qur'an dan Hadis. ${ }^{14}$ Pentingnya pasar dalam Islam tidak terlepas dari fungsi pasar sebagai wadah bagi berlangsungnya kegiatan jual beli. ${ }^{15} 39$ Konsep Islam menerangkan bahwa pasar dapat berperan efektif dalam kehidupan ekonomi jika prinsip persaingan bebas dapat diaplikasikan secara efektif. ${ }^{16}$

Prinsip-prinsip pemasaran Islami menurut Abdullah Gymnastiar dan Hermawan Kertajaya yaitu; ${ }^{17}$

Pertama, Berlaku adil. Pada intinya kompetitor akan memperbesar pasar, sebab tanpa kompetitor industri tidak dapat berkembang dan kompetitor ini perlu diikuti mana yang bagus dan mana yang jelek, dimana kompetitor yang bagus perlu ditiru. Kedua, Tanggap terhadap perubahan. Selalu ada perubahan dalam kegiatan perindustrian, sehingga langkah bisnis akan terus berubah untuk

${ }^{13}$ Trias Aprilya, "Strategi Komunikasi Pemasaran Nadyafashop Melaluo Instagram dalam Meningkatkan Kepercayaan Customer di Samarinda”, eJournal Ilmu Komunikasi, 2017, hlm. 14

14 Bukhari Alma dan Donni Juni Priansa, Manajemen Bisnis Syariah: Menanamkan Nilai dan Praktis Syariah dalam Bisnis Kontemporer, Bandung: Alfabeta, hlm. 340 menyesuaikan dengan pasar. Kompetisi yang semakin sengit tidak dapat dihindari, arus globalisasi dan teknologi akan membuat pelanggan semakin pintar dan selektif sehingga jika kita tidak sensitif terhadap perubahan maka kita akan kehilangan pelanggan.

Ketiga, Berbuat yang terbaik dari sisi produk dan harga. Dalam konsep pemasaran Islami, tidak diperbolehkan menjual barang jelek dengan harga yang tinggi, hal ini dikarenakan pemasaran islami adalah pemasaran yang adil dimana harga sesuai dengan barang atau produk. Keempat, Rela sama rela dan adanya hak khiyar pada pembeli (hak pembatalan terhadap transaksi). Pada prinsip ini, pemasar yang mendapatkan pelanggan haruslah memelihara hubungan yang baik dengan mereka. Dan dipastikan pelanggan puas terhadap pelayanan yang diberikan, sehingga pelanggan menjadi lebih royal. Kelima, Tidak curang dan Berorientasi pada kualitas. Dalam pemasaran Islami curang sangatlah dilarang, seperti penipuan menyangkut kuantitas, kualitas, dan waktu penyerahan barang dan harga. Tugas seorang marketer adalah selalu meningkatkan kualitas barang dan jasa agar tidak kehilangan pelanggan.

15 Sukarno Wibowo dan Dedi Supriadi, Ekonomi Mikro Islam, Bandung: Pustaka Setia, 2013, hlm. 201

16 Mustafa Edwin Nasution, et. al., Pengenalan Ekslusif Ekonomi Islam, Jakarta: Prenada Media Group, 2014, hlm. 160.

17 Abdullah Gymnasiar dan Hermawan Kertajaya, Berbisnis Dengan Hati, Jakarta: Mark Plus \& CO, 2004. hlm. 46 


\section{Hasil dan Pembahasan \\ Profil PT. Ojek Syari}

PT. Ojek Syari didirikan pada tanggal 10 Maret 2015 oleh Evilita Adriani mahasiswi UPN Veteran Surabaya jurusan Hubungan Internasional dan Reza Zamir dengan nama Ojek Syar'i Surabaya. Pada tanggal 8 Agustus 2015 Agus Edi S bergabung dan berubah menjadi PT. Ojek Syari dengan legalitas PT. Ojek Syari Indonesa disahkan akta Notaris Wiedha Restya Rachmayani, S.H.,M.Kn. Nomor 01 .

Tahun 2015 kantor PT. Ojek Syari berada di Sawahan Baru 2/ 73 Surabaya, tahun 2016 kantor berpindah ke Tropodo Sidoarjo, dengan pertimbangan berbagai hal 2017 kantor PT. Ojek Syari berpindah tempat di Jl. Raya Margomulyo 150, Kabupaten Bojonegoro. Tahun 2018 kantor PT. Ojek Syari merencanakan pindah kembali di Surabaya untuk kantor sementara di inkubator bisnis UPN Veteran Surabaya.

Awal berdiri CEO PT. Ojek Syari lah yang menjadi driver sebelum direkrutnya driver-driver baru, tahun 2015 PT. Ojek Syari cakupan wilayahnya hanya di Surabaya, setelah beberapa tahun order semakin meningkat, pada awal tahun 2016 mulailah mengembangkan pembuatan aplikasi PT. Ojek Syari. Januari 2016 Ojesy meluncurkan aplikasi android, namun masih tahap test dan tidak untuk di komersilkan. Dan mendaftarkan merek “Ojesy" di Dirjen HKI. Maret 2016 memiliki 300 Sahabat Pengendara Wanita.
Motivasi dasar PT. Ojek Syari adalah "sebaik-baiknya manusia adalah yang paling bermanfaat" kalimat tersebut merupakan hadist sahih dari Nabi Muhammad SAW. Sehingga PT. Ojek Syari disini memiliki visi adalah "memberdayakan wanita lebih banyak sehingga dapat membantu lebih banyak". Dalam artian wanita yang diajak bergabung menjadi sahabat pengendara, akan membantu penumpang wanita yang membutuhkan transportasi yang aman, dan juga akan menambah pendapatan keluarganya sehingga hidupnya akan lebih sejahterah.

Komitmen PT. Ojek Syari adalah berkembang ke berbagai kota dengan target pengembangan adalah 50 kota besar di Indonesia dalam 5 tahun, menambah layanan yang bervariatif untuk bisa meningkatkan kesejahteraan wanita dengan berbagai pilihan pekerjaan. ${ }^{18}$

\section{Langkah Strategis PT. Ojek Syari dalam Mencapai Tujuannya}

Setiap perusahaan baru pasti akan melakukan strategi dalam mengembangkan bisnis barunya hal itu juga dilakukan oleh PT. Ojek Syari. Proses perencanaannya meliputi segmentantasi pasar, penentuan target pasar, positioning, penetapan produk, penetapan tarif, penetapan tempat atau lokasi layanan, penetapan promosi, penetapan SDM, sarana fisik, proses.

PT. Ojek Syari menetapkan wanita dan anak-anak sebagai sasaran pasarnya. Berbagai pertimbangan yang dilakukan

\footnotetext{
${ }^{18}$ Hasil wawancara dengan Evilita Adriani, pada 17 Maret 2018
} 
PT. Ojek Syari dalam memilih sasaran tersebut melalui proses segmentasi pasar akan didapat sasaran pasar, setelah itu tahap positioning. dari proses itu didapati bahwa alasan utama PT. Ojek Syari memilih segmen wanita dan anak-anak yaitu para kompetitor ojek online seperti Go-jek, Grab, Uber sasaran pasarnya umum tidak spesifik, PT. Ojek Syari menawarkan sebuah segmen yang berbeda PT. Ojek Syari tahu bahwa kalau memilih segmen yang sama dengan Go-jek, Grab, Uber pasti akan kalah karena perusaahan ojek online tersebut sudah ada lebih dulu, misalnya Uber dengan segmen yang sama seperti Go- Jek dan Grab tetapi tidak lama bertahan di Indonesia baru-baru ini dikabarkan sudah hengkang dari wilayah Asia tenggara.

Masyarakat Indonesia sekarang ini berbondong-bondong lagi hijrah ingin serba syar' $i$, lebih agamis baik dikalangan artis-artis, ibu-ibu sosialita, remaja, ibu-ibu muda, orang tua semua ingin serba syar' $i$, mulai dari pakaian, gaya hidup, makanan, bisnis dan juga tingkat kejahatan ataupun kekerasan perempuan dan anak-anak dalam transportasi umum meningkat setiap tahunnya dari situ perempuan yang akan dirugikan, di sini peluang PT. Ojek Syari, PT. Jika dianalisis lebih dalam strategi PT. Ojek Syari dalam menggarap segmen wanita dan anak-anak itu sudah sangat jitu belum ada perusahaan sejenis dengan menggarap pangsa pasar itu yang ada transportasi umum khusus wanita tetapi berbasis konvensional seperti bus khusus perempuan dan anak-anak, kereta api yang memang khusus untuk tempat duduk perempuan, tetapi transportasi umum tersebut belum memanfaatkan teknologi yang ada. Misalnya bus dalam kota jika ingin naik harus menunggu dijam-jam tertentu baru lewat jika sudah lewat atau tertinggal harus menunggu lama untuk perjalanan selanjutnya itu pun belum tentu bus yang khusus perempuan.

Jika di kereta api yang cakupannya dalam kota seperti KRL sudah banyak disediakan tempat duduk untuk perempuan digerbong-gerbong tertentu namun di lapangan sering didapati jika sudah penuh laki-laki pun bisa duduk bebas disana tanpa ada pengawasan dari petugas. PT. Ojek Syari hadir dengan teknologi canggihnya dan basis syar' $i$ untuk problem tersebut.

Pemilihan segmen PT. Ojek Syari itu sudah sangat baik dan sangat tepat, disisi lain PT. Ojek Syari juga menggunakan strategi penetapan produk disini PT. Ojek Syari menentukan tiga layanan yaitu ojek regular, ojek langganan, ojek kurir dari semua layanan ojek langganan paling diminati, PT. Ojek Syari belum mengembangkan secara maksimal layanan yang kurang diminati hanya layanan langganan saja yang difokuskan jika tidak ada pengembangan lebih lanjut lebih baik layanan yang kurang diminati itu dihapus untuk fokus ke langganan atau diganti dengan layanan baru yang bisa dikerjakan secara maksimal.

Penentuan lokasi layanan pada PT. Ojek Syari untuk langkah awal memilih kota Surabaya sebagai kantor pusat itu sudah bagus karena pada tahun 2015-2016 waktu itu Go-Jek dan Grab berpusat di Jakarta belum sampai ke Surabaya, namun satu tahun berdiri kantorpun berpindahpindah tempat ke Sidoarjo, Bojonegoro, 
dan kembali ke Surabaya dihitug sudah hampir tiga kali pindah, pindah-pindah kantor pusat ini dapat menghambat perkembangan bisnis PT. Ojek Syari di tengah persaingan bisnis yang kuat karena dengan berpindah-pindah akan memakan waktu untuk perekrutan karyawan baru, training karyawan, riset lokasi. Sebaran pengendara dikota- kota pun kurang terlihat hanya pencantuman lokasi kota yang dibuka, berdasarkan uraian data yang terdapat di bab sebelumnya bahwa pelanggan terbanyak terdapat di kota Surabaya. Tapi pada kenyataannya di kota Surabaya sendiri banyak orang yang belum tahu, belum se booming Go-jek, Grab, Uber dari sisi promosinya pun belum dimaksimalkan.

Sayangnya pada pemilihan promosi PT. Ojek Syari menggunakan pola-pola tradisional yaitu menggunakan penjualan personal, online marketing, periklanan itu sangat konvensional, seharusnya memilih pola-pola promosi yang canggih, memilih social media advertising itu sudah canggih namun kenyataan dilapangan kurang dimaksimalkan misalnya, menggunakan sistem endorse di media sosial berkerja sama dengan artis berfigur muslimah iklannya hanya dua minggu sekali. Sedangkan setiap beberapa hari sekali jika orang lebih banyak yang tahu PT. Ojek Syari peluang mengembangkan sebaran pengendara di kota-kata di Indonesia akan lebih banyak. Event sering kali PT. Ojek Syari pada pameran-pameran besar namun eksekusi kurang maksimal hanya mendisplai, pemberian brosur-brosur ke pengunjung ini menggunakan cara yang membosankan harusnya memakai pola- pola interaktif mengadakan games, undian atau lainnya.

Dari pemilihan sumber daya manusia pun juga belum dimaksimalkan seperti custumer servis antara sosial media, telepon, pemesanan order ini tidak dibedakan tugasnya dijadikan satu dihandle oleh satu CS dengan 2 shift 05.0013.00 dan 13.00-21.00, ini tidak maksimal dalam berkerja karena beban kerja terkadang jika banyak komen di sosial media terkadang kepala pemasaran turun langsung untuk membalas komentarkomentar. Seperti baru- baru ini viral postingan PT. Ojek Syari di posting artis berjilbab Dewi Sandra banyak sekali komentar yang perlu dibalas sampaisampai kepala pemasaran pun ikut membantu. Jika dalam dunia profesional bisnis pembagian wilayah kerja itu sangat penting agar tidak terdapat beban kerja berlebih yang tidak sesuai dengan jabatannya.

Dalam penentuan segmentasi PT. Ojek Syari sangat berani mengambil sasaran wanita dan anak-anak yang tidak diambil oleh perusahaan ojek online lainnya hal itu strategi yang sangat bagus apalagi dibungkus dengan basis syar' $i$ hal ini menjadi solusi problem wanita dan anak-anak dalam angkutan umum, namun memilih segmen berbeda tapi hasilnya kurang heboh jika dilihat di Surabaya keberadannya kurang diketahui masih belum banyak yang tahu. Kelemahannya pada kurang memaksimalkan pola promosi yang canggih, pengelolaan SDM, manajamen yang tertata, mendatangi kerjasama dengan muslimah, dalam segmentasi sudah bagus tapi tidak 
didukung mangemen yang bagus hasilnya kan biasa saja tidak heboh dan viral, jadi strategi komunikasi pemasaran belum bisa dijalankan dengan baik

\section{Bentuk Komunikasi Pemasaran PT. Ojek Syari}

Bentuk komunikasi pemasaran PT. Ojek Syari adalah melalui sosial media marketing yaitu melalui Instagram, Youtube, Facebook baik melalui posting ataupun bentuk sosial media advertising konten isi dari sosial media ini berdasarkan syari'i yaitu lebih mengutamakan aspek Islami ajakan kebaikan, ayat Al-Quran, Hadist, tata cara hidup yang sesuai ajaran Islam, hari-hari besar Islam, sunnahsunnah. Repost dari laman berita di Instagram misalnya saja Islamfact.id, @islamiQpedia.

Pada media televisi PT. Ojek Syari juga menggunakannya, seperti liputan acara Islami TV UMMAT di Transtv. Program Talkshow khusus perempuan Curahan Hati Perempuan di Trans TV. Pada media radio PT. Ojek Syari pernah menjadi pengisi acara LIVE dalam TalkShow di Suara Muslim, dan juga artikel yang dimuat oleh media cetak Nurul Hayat.

Selain itu media TV lokal maupun swasta banyak sekali yang meliput PT. Ojek Syari bahkan media luar negeri karena dianggap inspiratif memecahkan banyak problem kekerasan seksual pada anak-anak dan perempuan.

\section{Sistem Pemasaran Syar'i dalam PT. Ojek Syari}

Sistem Syar'i dalam PT. Ojek Syari diterapkan pada pembagian hasil, proses perekrutan, proses promosi, konten sosial media, sampai tata cara berkendara yang syar' $i$, dan cara berpakaian. Basis syar' $i$ dalam PT. Ojek Syari ini meliputi cara pembagian hasil dengan $80 \%$ untuk pengendara $20 \%$ untuk manajemen, intinya syari dalam pembagian hasil di PT. Ojek Syari itu sesuai dengan tenaga, waktu dan kebutuhan saat berkendara oleh pengendara, dipotong 20\% untuk tenaga karyawan dan manajemen. Yang kedua adalah saat proses transaksi atau saat pelayanan pengendara wajib memberikan salam "Assalamualaikum" berkendara dengan sopan santun memperhatikan rambu-rambu, perekrutan karyawan di Ojek dalam proses perekrutan karyawan dan pengendara menggunakan surat izin jika sudah menikah surat izin dari suami, jika belum menikah surat izin dari orang tua. Selanjutnya pakaian karyawan dan pengendara harus berjilbab dan menggunakan pakaian tidak selalu gamis yang panjang tapi pakaian yang sopan tidak ketat yang nyaman dan aman digunakan untuk berkendara. Sistem ini tidak ditawarkan bisnis transportasi online lain yang sejenis hanya di PT. Ojek Syari yang berani mengambil basis tersebut.

Ada beberapa tahapan dalam mencapai tujuannya, yaitu; Tahap Segmentasi, Penentuan Target Pasar, Positioning Produk pada tahap segmentasi PT. Ojek Syari memilih wanita dan anakanak pada didasarkan pada melihat segmentasi dari kompetitor ojek online lain 
seperti Go-jek, Grab, Uber sasaran pasarnya umum, maka dari itu cari segmen yang berbeda agar lebih menarik pasar. Penentuan nama PT. Ojek Syari didasari konsep di awal segmentasinya perempuan dan pengendaranya adalah perempuan muslimah dan juga CEO PT. Ojek Syari mengarahkan bisnis ini berbasis Islam yang sesuai syari yaitu dengan pertimbangan di Indonesia adalah mayoritas Muslim. PT. Ojek Syari mengusung take line "solusi dan kemudahan.

Tahap penentuan produk di PT. Ojek Syari produknya berupa layanan-layanan yang disediakan yang sangat memudahkan penumpang dan pengendara terdapat tiga layanan yang pertama adalah layanan ojek regular, layanan ojek berlanggananlayanan kurir barang.

Tahap penentapan harga setiap kilometer pengendara mengeluarkan biaya apa saja seperti oli,bensin, helm,jaket, perawatan motor, semua menghasilkan angka bahwa $1 \mathrm{~km}$ mereka itu mengeluarkan biaya sekitar Rp 600,- jika dihitung tarif Rp 3.000,- . dengan sistem bagi hasilnya $80 \%$ jadi tinggal Rp. 2.400,dikurangi Rp 600,- jadi mereka dapat bersihnya yaitu Rp 1.900,00 per kilometer. Jika hitung-hitung apabila pengendara ambil 8 order sehari dalam satu bulan itu hampir menyamai UMR.

Dalam sekali order PT. Ojek Syari mematok $5 \mathrm{~km}$ untuk jarak minimal tempuh, tarif per kmnya adalah Rp 3.000,. Jika ditotal untuk tarif minimal sekali perjalan adalah Rp 15.000,. Tarif berlangganan bulanan hanya cukup memesan layanan 1 kali dalam 1 bulan dan
1 kali bayar. Tarif berlangganan minimal 20 kali, akan berikan diskon Rp 5000,- per order nya..

Tahap penentuan lokasi layanan PT. Ojek Syari tidak mengandalkan tempat tidak mengandalkan kantor tapi persebaran pengendaranya itu ada di wilayah apa aja penyebarannya. Dasar penentuan kota sebaran PT. Ojek Syari yaitu ; di kota besar, aktifitas wanitanya padat, suda mulai teknologi, mayoritas agama Islam.

Tahap Penentuan Promosi dalam hal ini PT. Ojek Syari menggunakan periklanan, online marketing, promosi penjualan, penjulan personal. Strategi promosi PT. Ojek Syari salah satunya melalui social media advertising di Facebook dan Instagram. Tahap Penentapan SDM pengendara dalam perekrutan pengendara beberapa persyaratan yang harus dipenuhi salah satunya berhijab dan surat izin bergabung dari suami atau orang tua.

Tahap Implementasi Dampak yang ditimbulkan dari implementasi strategi komunikasi pemasaran yaitu sebagai berikut: (1) naik turunnya pendapatan, (2) peningkatan jumlah pengguna PT. Ojek Syari sebesar 57\%. Bentuk komunikasi pemasaran PT. Ojek Syari adalah melalui sosial media marketing yaitu melalui Instagram, Youtube, Facebook konten isi dari sosial media ini berdasarkan syari'i yaitu lebih mengutamakan aspek Islami Sistem syar'i.

Sistem Syar'i dalam PT. Ojek Syari diterapkan pada pembagian hasil, proses perekrutan, proses promosi, konten sosial media, sampai tata cara berkendara yang syar' $i$, dan cara berpakaian. Tetapi tidak 
semua diterapkan dalam seluruh aspek bisninnya. Dan juga melalui media TV, radio, cetak. Media yang digunakan PT. Ojek Syari tersebut berbasis Islami. Dari semua tahap PT. Ojek Syari bagus dan jitu dalam segementasi memilih wanita dan anak-anak, dan penetapan produk tetapi lemah dan kurang maksimal dalam tahap promosi, pengelolaan SDM, dan penentuan lokasi.

Jika di Analisis lebih mendalam ditemukan bahwa sistem syar'i adalah pemasaran syar' $i$ adalah strategi pemasaran, yang harus memayungi seluruh aktivitas dalam sebuah perusahaan, meliputi seluruh proses, menciptakan, menawarkan, pertukaran nilai, dari seorang produsen, atau satu perusahaan, atau perorangan, yang sesuai dengan ajaran Islam. Pada PT Ojek Syari sistem syar' $i$ ini diterapkan secara baik namun tidak semua aspek yang berbasis syar' $i$ dikarenakan ini menyesuaikan kebutuhan yang terdapat dalam pereusahaan tersebut. Tentunya kedepannya PT. Ojek Syari akan menerapkan sistem syar'i dalam semua aspek bisninya.

Dari berbagai cara yang dilakukan oleh PT. Ojek Syari ini apabila ditinjau dari segi teori Teori bauran promosi jasa atau biasa disebut 7P yang menyaakan mempunyai 7 unsur yaitu yaitu prouct (produk), price (harga), place (tempat atau lokasi) dan promotion (promosi) yang diperluas dengan penambahan unsur nontraditional bauran pemasaran, yaitu people (orang), physical evidence (fasilitas fisik) dan process (proses), sehingga menjadi unsur 7P.
Sesuai dengan paparan tentang produk yang dikemukakan di atas, maka PT. Ojek Syari sebagai perusahaan jasa transportasi online memiliki produk inti atau generik berupa layanan ojek online khusus wanita dan anak-anak. Sedangkan produk pelengkap yang ditawarkan, antara lain; jaminan keamanan dan kenyamanan, kemudahan pepemesanan melaui aplikasi, merek terkenal khusus wanita dan anakanak, menerapkan basis syar' $i$.

Pemilihan tempat atau lokasi memerlukan pertimbangan yang cermat terhadap beberapa faktor berikut; akses, visibilitas, lalu lintas, tempat parkir, ekspansi, lingkungan, persaingan, peraturan daerah. Lokasi kantor pusat PT. Ojek Syari terdapat di Bojonegoro sebelumnya berada di Surabaya lalu Sidoarjo dari sini sudah terlihat penentuan lokasi belum tetap masih berpindahpindah. Dalam PT. Ojek Syari jika menurut standar penetapan tempat di atas PT. Ojek Syari kurang memenuhi syarat penentapan lokasi layanan berdasarkan teori 7P. PT. Ojek Syari tidak mengandalkan tempat tidak mengandalkan kantor tapi persebaran pengendaranya yang ada di wilayah apa saja.

Dalam PT. Ojek Syari jika menurut standar di atas beberapa saja yang terpenuhi, yang terpenuhi yaitu (1) mempertimbangkan sejumlah faktor dalam menetapkan harga PT. Ojek Syari menetapkan harga berdasarkan UMR per daerah yang di buka cabang PT. Ojek Syari, aktivitas wanitanya padat, sudah masuk teknologi. (2) berbagai jenis biaya harus dipertimbangkan dalam menetapkan harga, PT. Ojek Syari mempertimbangkan 
biaya yang dikeluarkan pengendara misal bensin, perawatan motor, helm, jas hujan dan mempertimbangkan biaya yang dikeluarkan manajemen untuk pembuatan aplikasi, gaji karyawan, biaya promosi dengan prosentase $80 \%$ untuk pengendara $20 \%$ untuk manajemen dengan hasil akhir Rp 3000,- per km. (3) mempertimbangkan harga pesaing, harga per $\mathrm{km}$ kompetitor dalam kisaran Rp 2.500,- PT. Ojek Syari relative lebih mahal 500 Rupiah karena jika lebih dari Rp 3000,- dirasa sudah terlalu mahal. Dalam PT. Ojek Syari jika menurut standar penetapan harga di atas PT. Ojek Syari kurang memenuhi syarat penentuan tarif berdasarkan teori 7P.

Dalam aspek ini PT. Ojek Syari menurut paparan di atas memenuhi standart berdasarkan teori 7P. Prosedur dalam menggunakan jasa PT. Ojek Syari sangat sederhana, sehingga konsumen dapat menikmati layanan- layanan dan fitur dengan mudah, dengan mendownload aplikasi PT. Ojek Syari di Playstore dan otomatis isntal dalam smartphone, langkah awal terlebih dahulu daftar dengan email untuk mengetahui data pelanggan setelah itu pilih layanan sesuai kebutuhan, menentukan pilihan lokasi jemput dan lokasi antar klik pesan, beberapa menit kemudian pengendara PT. Ojek Syari datang dan mengantar ke lokasi tujuan, setelah sampai bayar sesuai dengan nominal dalam aplikasi. Sedangkan untuk berlangganan di awal pembayaran menentukan jadwal dalam satu bulan dijemput dan diantar berapa kali serta jam juga disesuaikan jika ad perubahan langsung menghubungi pengendara langsung kareana terdapat fasilitas satu driver satu pelanggan.

Dalam konteks realita di PT. Ojek Syari, apa yang terjadi di PT. Ojek Syari memperlihatkan bagaimana teori ini itu tidak berkerja secara maksimal hanya dibagian - bagian tertentu saja misalnya maksimal pada segmentasi dan penetapan produk, penentuan tarif dan proses selama melakukan order Tampak peneliti melihat bahwa PT. Ojek Syari memaksimalkan dalam proses penentuan segmentasi dan penentuan produk saja dari sekian banyak strategi berdasarkan teori ini mempunyai kekuatan di segmetasi produk tapi lemah di sektor promosi, penetapan lokasi layanan dan pengelolaan SDM.

\section{Kesimpulan}

Berdasarkan data yang diperoleh dari lapangan dan setelah dikonfirmasikan dengan teori yang ada, peneliti dapat menarik kesimpulan, sebagai berikut;

Strategi komunikasi pemasaran yang dilakukan oleh PT. Ojek Syari mengacu pada perencanaan yang dilakukan oleh PT. Ojek Syari, dimana dalam perencanaan tersebut terdapat beberapa tahapan yang harus dilalui oleh PT. Ojek Syari agar bisa mencapai tujuan utamanya. Tujuan utamanya adalah menawarkan dan menginformasikan layanan jasa transpotasi online berbasis syar'i.

Terdapat enam tahapan yang harus dicapai sebelum mencapai tujuannya (1) Tahap segmentasi, penentuan target pasar, positioning produk, (2) tahap penentuan produk, (3) tahap penentuan harga/tarif, (4) tahap penentuan pempat/lokasi pelayanan, 
(5) tahap penentuanpPromosi, (5) tahap penetapan SDM, (6) tahap implementasi.

\section{Daftar Pustaka}

Departemen Agama RI. 2008. Al-Qur'an dan Terjemahannya, dengan transliterasi Arab-Latin. Surabaya: Fajar Mulya

Bungin, Burhan. 2013. Metodologi Penelitian Sosial\&Ekonomi. Jakarta: Kencana Prenada Media Group.

Suyanto, M. 2007. Markring Strategy Top Brand Indonesia. Yogyakarta: Andi

Uchjana,Effendy Onong. 2007. Ilmu Komunikasi (Teori dan Praktek). Bandung: PT Remaja Rosdakarya.

Mukhta. 2007. Bimbingan Skripsi, Tesis dan Artikel Ilmiah: Panduan Berbasis Penelitian Kualitatif Lapangan dan Perpustakaan. Jakarta: GP Press.

Sugiyono. 2009. Metode Penelitian Bisnis Pendekatan Kuantitatif, Kualitatif, dan $R \& D$. Bandung: Alfabeta.

J. Maleong, Lexy. 2002. Metodologi Penelitian Kualitatif. Bandung; Remaja Rosda Karya

Emzir. 2011. Analisis Data: Metodologi Penelitian Kualitatif. Jakarta :Rajawali Pers.

Kasali, Rhenald. 2007. Segmentasi, Targeting, dan Positioning. Jakarta: PT. Gramedia Pustaka Utama.

Soemanegara. 2006. Strategic Marketing Communication. Bandung: Alfabeta Sutisna. 2002. Perilaku Konsumen dan Komunikasi Pemasaran. Bandung: Remaja Rosdakarya.

Morissan. 2012. Periklanan : Komunikasi Pemasaran Terpadu. Jakarta: Kencana Prenada Media Group.
Aksa, Nur Syam. 2014. Pengantar Transportasi Wilayah Dan Kota Cet. I:Makassar; Universitas Alauddin.

Hurriyati, Ratih. 2008 Bauran Pemasaran dan Loyalitas Konsumen. Bandung: Alfabeta.

Swastha, Basu dan Irawan, 1997. Manajemen Pemasaran Modern. Yogyakarta: Liberty.

Alma, Bukhari dan Priansa, Donni Juni. Manajemen Bisnis Syariah: Menanamkan Nilai dan Praktis Syariah dalam Bisnis Kontemporer, Bandung: Alfabeta.

Wibowo, Sukarno dan Supridi, Dedi. 2013. Ekonomi Mikro Islam. Bandung: Pustaka Seti

Nasution, Mustafa Edwin. 2014. Pengenalan Ekslusif Ekonomi Islam, Jakarta: Prenada Media Group

Gymnasiar, Abdullah dan Kertajaya, Hermawan. 2004. Berbisnis Dengan Hati. Jakarta: Mark Plus \& CO Aksa.

Nur Syam. Pengantar Transportasi Wilayah Dan Kota. Cet. I:Makassar; Universitas Alauddin

Wahid Umaimah, dan Eka Puspita, Anggun. 2017. Jurnal Komunikasi. Upaya Peningkatkan Brand Awareness PT. GoJek Indonesia Melalui Aktivitas Marketing Public Relation. Vol. 9, No. 1.

Aprilya, Trias. 2017. eJournal Ilmu Komunikasi, Strategi Komunikasi Pemasaran Nadyafashop Melaluo Instagram dalam Meningkatkan Kepercayaan Customer di Samarinda

Citra A, Marsela.2017. Manajemen Komunikasi Pemasaran di Media Online (Studi Kasus terhadap Manajemen Komunikasi Pemasaran yang Dilakukan oleh 
GO-JEK di Media Online). Skripsi.

Skrips. Universitas Gadjah Mada

Yogyakarta

Trinanda Talaohu, Muhammad Dipo.

"Komunikasi Pemasaran

Transportasi Berbasis Online".

Skripsi. Bandung: Universitas Islam

Bandung.

Fauzi, Ahmad. 2017 Komunikasi Pemasaran UKM Kacapuri dalam Menarik Konsumen. Surabaya: Universitas Islam Negeri Surabaya.

yang Mengalami Kecelakaan Berdasarkan Undang- undang Tentang Perlindungan Konsumen, Skripsi. Medan : Universitas Sumtra Utara.

Hasil Survei Penetrasi dan Perilaku Pengguna Internet Indonesia 2017, https://apjii.or.id

http://www.ojeksyari.com/ 